\title{
Carcass and meat traits of goats fed diets containing cottonseed cake
}

\author{
Dallyson Yehudi Coura de Assis ${ }^{1}$, Fabiano Almeida de Oliveira ${ }^{1}$, Edson Mauro Santos ${ }^{2}$, \\ Ana Alice Lima de Gouvêa ${ }^{1}$, Bruna Maria Aparecida de Carvalho ${ }^{3}$, Camila de Oliveira Nascimento ${ }^{1}$, \\ Luís Gabriel Alves Cirne ${ }^{4}$, Douglas dos Santos Pina ${ }^{1}$, Aureliano José Vieira Pires ${ }^{5}$, \\ Henry Daniel Ruiz Alba ${ }^{1}$, and Gleidson Giordano Pinto de Carvalho ${ }^{1}$ \\ ${ }^{1}$ Department of Animal Science, Universidade Federal da Bahia, \\ Salvador, Bahia, Code 40170-110, Brazil \\ ${ }^{2}$ Department of Animal Science, Universidade Federal da Paraíba, \\ Areia, Paraíba, Code 58397-000, Brazil \\ ${ }^{3}$ Institute of Agrarian Sciences, Universidade Federal de Minas Gerais, \\ Montes Claros, Minas Gerais, Code 39404-547, Brazil \\ ${ }^{4}$ Institute of Biodiversity and Forestry, Universidade Federal do Oeste do Pará, \\ Santarém, Pará, Code 68035-110, Brazil \\ ${ }^{5}$ Department of Animal Science, Universidade Estadual do Sudoeste da Bahia, \\ Itapetinga, Bahia, Code 45700-000, Brazil
}

Correspondence: Gleidson Giordano Pinto de Carvalho (gleidsongiordano@yahoo.com.br)

Received: 23 December 2020 - Revised: 8 July 2021 - Accepted: 10 August 2021 - Published: 20 September 2021

\begin{abstract}
The cottonseed cake has the necessary nutritional characteristics to be able to substitute the traditional ingredients (such as soybean meal) and reduce the costs of the diet. However, it is necessary to determine the best level of inclusion of cottonseed cake in the diets of fattening goats to improve meat production and quality. The objective of this study was to evaluate carcass and meat traits of feedlot goats fed diets containing cottonseed cake replacing soybean meal $(33 \%, 66 \%$ and $100 \%)$. Thirty-two uncastrated Boer crossbred goats (4 months old, $16 \pm 2 \mathrm{~kg}$ initial body weight) were used in a completely randomized experimental design. Replacing soybean meal with cottonseed did not compromise $(P>0.05)$ slaughter weight, carcass traits (dressing percentage, loineye area and back-fat thickness), primal cuts or carcass morphometric measurements; moisture, protein, or total lipid contents of meat; or the physicochemical traits of color ( $L^{*}, a^{*}$ and $b^{*}$ coordinates), $\mathrm{pH}$, shear force, and cooking loss. However, there was a reduction $(P=0.001)$ in the mineral matter content (from $1.08 \%$ to $0.97 \%$ ) and an increase $(P=0.006)$ in the cholesterol content (from 50.85 to $70.55 \mathrm{mg} / 100 \mathrm{~g}$ of meat) of the meat as the dietary levels of cottonseed cake were increased. Based on the results of production and meat quality, we recommend using cottonseed cake as an alternative protein source to replace up to $100 \%$ of soybean meal in feedlot goat diets.
\end{abstract}

1

Introduction

Goats are hardy, prolific animals with high ability to adapt to adverse climatic conditions. The species is widespread around the world (Dubeuf, 2011; Iñiguez, 2011) and constitutes an important source of meat, milk, and skin. However, when reared in extensive systems in the semiarid environ- ment, which is characterized by seasonal herbage production, their production performance is not satisfactory.

For these animals, feedlotting can be used as a tool to improve weight gain, carcass quality, and the meat product, as a result of a younger age at slaughter. To achieve these ends, goat diets must include traditional feedstuffs such as soybean and corn, which can account up to $70 \%$ of the costs of an animal production system (McGrath et al., 2018). 
Therefore, producers seek alternative feed sources that allow a reduction in production costs and minimize nutritional deficiency for the development of meat goat farming. In this context, the use of biodiesel by-products in the diet of these animals may be a viable alternative, given their positive effects on meat and milk quality, as observed in other animal species (Gonzaga Neto et al., 2015; Oliveira et al., 2015). Cotton by-products have nutritional characteristics that render them good sources of nutrients for animal feeding. Cottonseed cake, for instance, has satisfactory protein $(>30 \%)$ and gross energy ( $>5.5 \mathrm{kcal} / \mathrm{g}$ per dry matter) contents for use in ruminant diets (Rekwot, 2004).

Pereira et al. (2016) evaluated the use of cottonseed cake in the diet of feedlot lambs and found that it improved the nutritional properties of their meat. However, despite this potential, there is still a dearth of research investigating this cotton by-product in finishing goat diets. On this basis, the present study proposes to examine the effects of replacing soybean meal with cottonseed cake on carcass and meat traits of feedlot goats.

\section{Material and methods}

\subsection{Experimental area}

The experiment was conducted at the Experimental Farm at the School of Veterinary Medicine and Animal Science at the Federal University of Bahia (EMEVZ-UFBA), located in São Gonçalo dos Campos - BA, Brazil (12 $23^{\prime} 57.51^{\prime \prime} \mathrm{S}$ and $\left.38^{\circ} 52^{\prime} 44.66^{\prime \prime} \mathrm{W}\right)$. All experimental procedures were in compliance with the Brazilian law on research involving animals and were approved by the Ethics Committee on Animal Use of EMEVZ-UFBA (approval no. 08/2013).

\subsection{Animals, facilities, and feeding management}

Thirty-two Boer crossbred goats (4 months old, $16 \pm 2 \mathrm{~kg}$ initial body weight) were used in the study. The animals were housed in individual suspended, slatted-floor pens (approximately $1.0 \mathrm{~m}^{2}$ ) equipped with individual feeding troughs and drinkers, inside a covered shed. At the start of the experiments, the goats were tagged, dewormed against ectoparasites, immunized with a multipurpose vaccine against clostridial infections, supplemented intramuscularly with vitamins A, D, and E, and allotted at random to the treatments, in a completely randomized experimental design.

The experimental period was $84 \mathrm{~d}$, which were preceded by $12 \mathrm{~d}$ of adaptation to the environment, management and diets. During this period, the animals were fed Tifton 85 grass (Cynodon sp.) hay and increasing amounts of a concentrate containing cottonseed cake, as follows: $80: 20$ (roughage-to-concentrate ratio; day 1), $70: 30$ (day 4), 60: 40 (day 7), and $50: 50$ (day 10). On the first evaluation day (day 13 ), the goats received a total diet with $50 \%$ roughage and $50 \%$ concentrate, which was maintained throughout the experiment.

The diets were provided in two daily meals $-50 \%$ at 08:00 and $50 \%$ at $16: 00$ - allowing $10 \%$ orts. Tifton 85 grass hay, which was used as a roughage source, was previously ground to particles of approximately $2 \mathrm{~cm}$. The concentrate portion of the diet was composed of ground corn, soybean meal, cottonseed cake, urea, ammonium sulfate, and a mineral supplement.

Treatments were represented by total diets in which soybean meal was replaced with cottonseed cake at 330,660, or $1000 \mathrm{~g} / \mathrm{kg}$ per dry matter (Table 1 ). The diets were formulated in accordance with the recommendations of the National Research Council (NRC, 2007), aiming to meet the requirements of goats with an estimated average daily gain of $150 \mathrm{~g}$.

Samples of diet ingredients and orts were harvested once weekly throughout the experimental period. These were packed in labeled plastic bags which were then stored in a freezer at $-20^{\circ} \mathrm{C}$ until analysis. After thawing, the samples were pre-dried in a forced-air oven at $55^{\circ} \mathrm{C}$ for $72 \mathrm{~h}$ and then ground through Willey knife mills to $1 \mathrm{~mm}$ particles which were subsequently stored for later laboratory analysis.

The chemical composition of the samples was analyzed in accordance with the analytical procedures suggested by the Association of Analytical Communities (AOAC, 1990), whereby the dry matter (DM; method 967.03), mineral matter (MM; method 942.05), crude protein (CP; method 981.10), and ether extract (EE; method 920.29) contents were determined. Neutral (NDF) and acid (ADF) detergent fiber contents were determined by the methodology proposed by Van Soest et al. (1991). The NDF content was corrected for the residual ash and protein (NDFap); the NDF residue was incinerated at $600^{\circ} \mathrm{C}$ for $4 \mathrm{~h}$ to correct the ash, while protein was corrected by subtracting the protein content in the NDF residue. Lignin was determined by method 973.18 of AOAC (2002), using the ADF residue. Non-fibrous carbohydrate (NFC) contents were calculated by the following equation, proposed by Detmann and Valadares Filho (2010): $\mathrm{NFC}=100-(\% \mathrm{MM}-\% \mathrm{EE}-\% \mathrm{NDFap}-\% \mathrm{CP})$.

Lastly, the total digestible nutrients (TDNs) were estimated by the formula suggested by Weiss (1999): $\mathrm{TDN}=\mathrm{DCP}+2.25 \times \mathrm{DEE}+\mathrm{DNFC}+\mathrm{DNDF}$, where DCP, DEE, DNFC, and DNDF are the digestible fractions of CP, EE, NFC, and NDF, respectively.

Orts were harvested daily before the morning feed supply and weighed on a digital scale to determine DM intake, which was calculated as the difference between the amounts of the nutrient present in the diet and in the orts, as given by the following formula: intake $(\mathrm{kg})=$ nutrient intake - nutrient in orts. 
Table 1. Centesimal composition of ingredients and chemical composition of experimental diets.

\begin{tabular}{lrrrr}
\hline Composition (g/kg per dry matter) & 0 & 330 & 660 & 1000 \\
\hline Cottonseed replacement level (g/kg per dry matter) & & \\
\hline Tifton-85 hay & 500 & 500 & 500 & 500 \\
Ground corn & 349 & 347 & 345 & 343 \\
Soybean meal & 120 & 80 & 40 & 0 \\
Cottonseed cake & 0 & 40 & 80 & 120 \\
Urea + ammonium sulfate & 16 & 18 & 20 & 22 \\
Mineral mixture* & 15 & 15 & 15 & 15 \\
\hline Chemical composition (g/kg per dry & matter) & & & \\
\hline Dry matter & 909.8 & 902.2 & 910.3 & 910.6 \\
Mineral matter & 5.73 & 5.74 & 5.74 & 5.74 \\
Crude protein & 147.7 & 141.7 & 141.2 & 143.4 \\
Ether extract & 23.2 & 28.6 & 32.5 & 36.8 \\
NDFap & 386.7 & 400.5 & 414.4 & 428.2 \\
Acid detergent fiber & 212.5 & 221.0 & 229.4 & 237.9 \\
Lignin & 31.6 & 35.9 & 40.2 & 44.5 \\
Total carbohydrates & 755.7 & 754.3 & 753.0 & 751.6 \\
Non-fibrous carbohydrates & 369.0 & 353.8 & 338.6 & 323.4 \\
Total digestible nutrients & 684.3 & 677.5 & 670.6 & 663.8 \\
\hline * Provides per kilogram, in active ingredients: calcium 120.00 g; phosphorus 87.00 g; sodium \\
147.00g; sulfur 18.00 g; copper 590.00 mg; cobalt 40.00 mg; chromium 20.00 mg; iron \\
1800.00 mg; iodine 80.00 mg; manganese 1300.00 mg; selenium, 15.00 mg; zinc 3,800.00 mg; \\
molybdenum 300.00 mg; and maximum fluorine 870.00 mg. phosphorus (P) solubility in citric \\
acid (min. 2\%) -95\%. \\
\end{tabular}

\subsection{Slaughter}

On the 84th day in the feedlot, the animals were transferred to a commercial meat-packing plant in the municipality of Pintadas (BA, Brazil). Once in the abattoir, the goats were fasted for $16 \mathrm{~h}$, during which period they remained at rest. Subsequently, they were weighed to determine the post-fasting slaughter weight (FSW).

The animals were stunned by electronarcosis, which was followed by the bleeding, skinning, and evisceration steps, in accordance with the current procedures provided for by the guidelines for humane handling, transport, and slaughter of livestock (FAO, 2001). The gastrointestinal tract content (measured as the difference between full and empty gastrointestinal tract) was used to determine empty body weight $(\mathrm{EBW}=\mathrm{FSW}-$ gastrointestinal content $)$, as proposed by Resende et al. (2017).

\subsection{Carcass traits, morphometric measurements, and primal cuts}

Once eviscerated, the carcasses were weighed to determine hot carcass weight $(\mathrm{HCW})$, which was then used to determine hot carcass yield $(\mathrm{HCY}=\mathrm{HCW} / \mathrm{FSW} \times 100)$. Next, the carcasses were transferred to a cold chamber at a temperature of $6^{\circ} \mathrm{C}$, where they remained $24 \mathrm{~h}$ hung by the tendons of the gastrocnemius muscle on appropriate hooks. Subse- quently, the dressing percentage was calculated as the ratio between HCW and EBW.

Loin-eye area (LEA) was determined by making a transverse section between the 12th and 13th thoracic vertebrae and outlining the area corresponding to the cranial portion of the loin on a transparency sheet. The following measurements were thus made: length $(A)$ and maximum depth $(B)$ of the longissimus lumborum muscle (in $\mathrm{cm}$ ), which were obtained using a ruler. Loin-eye area was then calculated by the following ellipse formula proposed by Silva Sobrinho (2003): $\operatorname{LEA}=(A / 2 * B / 2) \pi$ (in $\left.\mathrm{cm}^{2}\right)$. Back-fat thickness (BFT) was measured in millimeters, using a digital caliper, at a 3/4 distance from the medial side of the longissimus muscle towards the spinous process.

After these analyses, the following carcass morphometric measurements were made: internal and external carcass length, chest and rump widths, chest depth, rump and thigh circumferences, and leg length. The length and circumference measurements were taken using a tape measure, whereas the width and depth measurements were obtained using a manual horse measuring stick.

The carcasses were divided lengthwise into two halves. The left half was sectioned into five anatomical regions called "primal cuts", namely, neck, shoulder, ribs, loin, and leg. The right and left loins from each animal were packed, labeled, and frozen $\left(-20^{\circ} \mathrm{C}\right)$ for later analyses of color, 
cooking loss (CL), shear force (SF), and centesimal composition.

\subsection{Evaluation of meat physicochemical traits}

After slaughter, the $\mathrm{pH}$ was measured in triplicate in the longissimus lumborum muscle, between the 12th and 13th thoracic vertebrae, using a stick-type digital $\mathrm{pH}$ meter (HI 99163m HANNA) with a penetration electrode.

The loins were thawed inside the plastic bags in a biooxygen demand (BOD) incubator at $10^{\circ} \mathrm{C}$ for $12 \mathrm{~h}$ and then dissected with a scalpel and a knife. Subsequently, the color was determined in the right loins using a colorimeter (Minolta CR-400) based on the CIELAB color space ( $L^{*}$ (lightness), $a^{*}$ (red intensity) and $b^{*}$ (yellow intensity)) calibrated to a white standard. Muscle color was determined in the inner part of the muscle $5 \mathrm{~min}$ after the cut was made in order to expose the myoglobin to oxygen, following Miltenburg et al. (1992).

To determine $\mathrm{CL}$, the samples were weighed and cooked in an industrial oven pre-heated to $170^{\circ} \mathrm{C}$ until the internal temperature in the geometric center of the samples reached $71^{\circ} \mathrm{C}$, which was measured with a thermocouple with a digital reader. Upon reaching that temperature, the samples were removed from the oven and weighed again for the calculation, with results expressed in percentage terms. Next, to determine meat tenderness based on SF (expressed in $\mathrm{N} / \mathrm{cm}$ ), the cooked samples were cut into $25 \times 25 \mathrm{~mm}$ cubes, in triplicate, and sectioned in the transverse direction of the muscle fibers using a texture analyzer ("texturometer") with a Warner-Bratzler blade, following the methodology of Wheeler et al. (1995).

For the chemical composition analysis, the samples were freeze-dried for $72 \mathrm{~h}$ and then ground through a ball mill to generate the laboratory sample. The chemical composition of the meat was determined by measuring the moisture, MM, $\mathrm{CP}$, and total lipid contents, following the methodology proposed by AOAC (1990).

Cholesterol was quantified by the enzymatic methodology, using Laborlab S/A laboratory kits, which were composed of two color reagents (no. 1, containing $0.025 \mathrm{~mol} / \mathrm{L}$ of 4 aminophenazone and no. 2, containing $0.055 \mathrm{~mol} / \mathrm{L}$ of phenol), in addition to an enzyme reagent (cholesterol oxidase $3 \mathrm{U} / \mathrm{mol}$, POD $20 \mathrm{U} / \mathrm{mol}$, lipase $300 \mathrm{U} / \mathrm{mol}$ ). The working reagent was prepared by adding $0.5 \mathrm{~mL}$ of color reagent no. $1,0.5 \mathrm{~mL}$ of color reagent no. $2,19 \mathrm{~mL}$ distilled water, and $0.4 \mathrm{~mL}$ of the enzyme reagent. After adding $3 \mathrm{~mL}$ of the working reagent to the samples, a thermal treatment was carried out for $10 \mathrm{~min}$ at $37^{\circ} \mathrm{C}$ in a water bath. After a $90 \mathrm{~min}$ rest, absorbance was read against the blank, also prepared at $499 \mathrm{~nm}$. The calibration curve was constructed from a standard cholesterol solution $(1006 \mathrm{mg} / 100 \mathrm{~mL})$ of concentration ranging from 0.01 to $0.05 \mathrm{mg} / \mathrm{mL}$.

\subsection{Statistical analysis}

The experiment was set up as a completely randomized design with four treatments and eight replicates, totaling $32 \mathrm{ex}-$ perimental units. Results were evaluated by variance and regression analyses, with the degrees of freedom decomposed by polynomial orthogonal contrasts into linear or quadratic effects, according to the cottonseed cake levels. The significance of regressions was determined by the $F$ test at the $5 \%$ probability level of type-1 error, using the PROC GLM and REG procedures of Statistical Analysis System (SAS, 2009). $P$ values between 0.05 and 0.10 were considered as trends.

\section{Results}

The intakes of DM, CP, NDF, NFC, and TDN were not changed $(P>0.05)$ by the dietary levels of cottonseed cake replacing soybean meal (Table 2). A quadratic effect on EE intake $(P=0.013)$ and a quadratic trend on PC intake $(P=0.079)$ were observed. Furthermore, the NFC intake showed a decreasing $(P=0.056)$ linear trend.

Post-fasting slaughter weight (average $22.47 \mathrm{~kg}$ ), EBW $(15.56 \mathrm{~kg}), \quad \mathrm{HCW}(12.00 \mathrm{~kg}), \quad \mathrm{HCY}(53.66 \%), \quad$ LEA $\left(10.68 \mathrm{~cm}^{2}\right)$, BFT $(1.21 \mathrm{~mm})$, and the yields of neck $(6.93 \%)$, shoulder $(26.69 \%)$, ribs $(20.48 \%)$, loin $(11.73 \%)$, and leg $(34.17 \%)$ also were not influenced $(P>0.05)$ by the replacement of cottonseed cake with soybean meal in the diet (Table 3). However, neck $(P=0.084)$ and leg $(P=0.086)$ yield showed a quadratic trend.

Internal and external carcass lengths, chest width and depth, and rump width and depth also did not differ $(P>0.05)$ (Table 4). Rump width showed an increasing $(P=$ 0.088 ) trend when soybean meal was replaced by cottonseed cake.

The $\mathrm{pH}$ measured immediately after slaughter, which averaged 6.55, color, measured in its coordinates $L^{*}(37.40), a^{*}$ (19.49), and $b^{*}(5.42), \mathrm{CL}(25.87 \mathrm{~g} / \mathrm{kg})$, and SF $(18.88 \mathrm{~N} / \mathrm{cm})$ in the longissimus lumborum muscle were not affected by the dietary replacement of soybean meal with cottonseed cake $(P>0.05)$ (Table 5).

The experimental diets did not alter $(P>0.05)$ the moisture $(746.5 \mathrm{~g} / \mathrm{kg})$, protein $(210.2 \mathrm{~g} / \mathrm{kg})$, or total lipid $(33.2 \mathrm{~g} / \mathrm{kg})$ contents of goat meat. By contrast, the MM content decreased (from 10.8 to $9.7 \mathrm{~g} / \mathrm{kg} ; P=0.001$ ) and the cholesterol levels increased (from 50.85 to $70.55 \mathrm{mg} / 100 \mathrm{~g}$ of meat; $P=0.006$ ) as soybean meal was replaced with cottonseed cake in the diets (Table 6).

Cooking losses $(P=0.059)$, moisture $(P=0.084)$, and total lipids $(P=0.080)$ of the goat meat showed quadratic effects when soybean meal was replaced by cottonseed cake.

\section{Discussion}

The similar intake values of the nutritional components indicate that the nutritional potential of cottonseed was effec- 
Table 2. Intake of nutritional components ( $\mathrm{kg}$ in the entire experimental period) of feedlot goats fed diets containing cottonseed cake replacing soybean meal.

\begin{tabular}{|c|c|c|c|c|c|c|c|}
\hline \multirow[t]{2}{*}{ Intake (kg) } & \multicolumn{4}{|c|}{$\begin{array}{l}\text { Cottonseed cake level } \\
\text { (g/kg per dry matter) }\end{array}$} & \multirow[t]{2}{*}{ SEM $^{*}$} & \multicolumn{2}{|c|}{$P$ value } \\
\hline & 0 & 330 & 660 & 1000 & & Linear & Quadratic \\
\hline Dry matter & 56.62 & 58.27 & 53.93 & 55.33 & 1.970 & 0.646 & 0.983 \\
\hline Crude protein & 9.40 & 12.43 & 11.16 & 11.33 & 0.390 & 0.208 & 0.079 \\
\hline Ether extract* & 0.93 & 0.73 & 0.85 & 1.00 & 0.019 & 0.297 & 0.013 \\
\hline NDFap & 20.11 & 25.07 & 20.01 & 23.62 & 1.063 & 0.567 & 0.764 \\
\hline Non-fibrous carbohydrates & 18.87 & 21.86 & 16.29 & 16.82 & 0.657 & 0.056 & 0.377 \\
\hline Total digestible nutrients & 31.36 & 31.55 & 27.82 & 30.18 & 1.967 & 0.684 & 0.779 \\
\hline
\end{tabular}

Table 3. Quantitative traits and yields of primal cuts from the carcass of feedlot goats fed diets containing cottonseed cake replacing soybean meal.

\begin{tabular}{|c|c|c|c|c|c|c|c|}
\hline \multirow[t]{2}{*}{ Item } & \multicolumn{4}{|c|}{$\begin{array}{l}\text { Cottonseed cake level } \\
\text { (g/kg per dry matter) }\end{array}$} & \multirow[t]{2}{*}{ SEM $^{*}$} & \multicolumn{2}{|c|}{$P$ value } \\
\hline & 0 & 330 & 660 & 1000 & & Linear & Quadratic \\
\hline \multicolumn{8}{|l|}{ Quantitative trait } \\
\hline Post-fasting slaughter weight, $\mathrm{kg}$ & 22.40 & 23.57 & 21.96 & 21.93 & 0.740 & 0.648 & 0.714 \\
\hline Empty body weight, kg & 15.50 & 16.69 & 14.87 & 15.16 & 0.656 & 0.627 & 0.762 \\
\hline Hot carcass weight, kg & 12.22 & 12.83 & 11.62 & 11.32 & 0.412 & 0.354 & 0.648 \\
\hline Hot carcass yield, $\%$ & 54.80 & 54.34 & 53.32 & 52.16 & 0.611 & 0.116 & 0.784 \\
\hline Loin eye area, $\mathrm{cm}^{2}$ & 10.79 & 10.97 & 10.63 & 10.31 & 0.150 & 0.187 & 0.419 \\
\hline Back-fat thickness, mm & 1.21 & 1.21 & 1.19 & 1.22 & 0.060 & 0.814 & 0.218 \\
\hline \multicolumn{8}{|l|}{ Cut yield (\%) } \\
\hline Neck & 6.47 & 7.36 & 7.18 & 6.72 & 0.154 & 0.731 & 0.084 \\
\hline Shoulder & 26.99 & 26.81 & 26.59 & 26.36 & 0.190 & 0.457 & 0.733 \\
\hline Ribs & 19.76 & 21.17 & 19.73 & 21.26 & 0.354 & 0.354 & 0.769 \\
\hline Loin & 12.35 & 11.23 & 11.89 & 11.45 & 0.373 & 0.682 & 0.654 \\
\hline Leg & 34.43 & 33.43 & 34.61 & 34.21 & 0.283 & 0.504 & 0.086 \\
\hline
\end{tabular}

${ }^{*}$ Standard error of the mean.

tive in replacing soybean meal in goat diets. Therefore, in the current study, the cottonseed inclusion in the diet did not promote satiety effects related to the chemical effect of meeting the energy requirements or the physical effect of rumen distension due to fiber intake (Allen, 2014; R. V. M. M. Silva et al., 2016). The quadratic effect of $\mathrm{EE}$ intake is related to the EE content of the diets, probably at $44.3 \mathrm{~g} / \mathrm{kg}$ per dry matter, the EE content of the diet when substituting soybean meal for cottonseed cake is low, thus promoting a lower intake of this nutrient. This theory can be supported by the trend observed in the intake of NFC, which decreases as the content of NFC in the diet is reduced.

On the other hand, considering the DM intake at the highest level of replacement of soybeans with cottonseed cake, EE intake was lower $(51.0 \%)$ and $\mathrm{CP}$ intake was higher $(42.9 \%)$ than expected. Considering the higher EE content and lower CP of cottonseed cake $(7.6 \%$ and $24.0 \%$, respectively) compared to soybean meal $(1.9 \%$ and $39.0 \%$, respectively) (R. V. M. M. Silva et al., 2016), the results of the current study indicate that there was a possible certain degree of feeding selectivity. The behavior of selectivity can be corroborated with the results found by Castro et al. (2020). These authors who evaluated cottonseed outlined in diets for finished sheep concluded that changes in nutrient intake were also due to selectivity. Furthermore, it is important to bear in mind that goats are the animals with the highest selectivity compared to sheep and cattle (Mohammed et al., 2020).

The similar values on quantitative traits and cut yields of the goats are probably related to the uniformity of age, initial live weight, breed, and sex class as well as the similar intakes of DM across the treatment groups. Therefore, the nutritional changes due to the total substitution of soybean meal for cot- 
Table 4. Morphometric measurements $(\mathrm{cm})$ of the carcass of feedlot goats fed diets containing cottonseed cake replacing soybean meal.

\begin{tabular}{|c|c|c|c|c|c|c|c|}
\hline \multirow[t]{2}{*}{ Item } & \multicolumn{4}{|c|}{$\begin{array}{l}\text { Cottonseed cake level } \\
\text { (g/kg per dry matter) }\end{array}$} & \multirow[t]{2}{*}{ SEM $^{*}$} & \multicolumn{2}{|c|}{$P$ value } \\
\hline & 0 & 330 & 660 & 1000 & & Linear & Quadratic \\
\hline External length & 42.00 & 40.87 & 42.25 & 42.50 & 2.81 & 0.534 & 0.547 \\
\hline Internal length & 50.42 & 50.50 & 49.00 & 49.37 & 2.21 & 0.235 & 0.835 \\
\hline Chest width & 15.00 & 14.37 & 16.25 & 15.43 & 1.94 & 0.345 & 0.863 \\
\hline Rump width & 11.71 & 12.81 & 13.43 & 13.50 & 1.89 & 0.088 & 0.477 \\
\hline Chest depth & 23.57 & 23.93 & 24.43 & 26.00 & 3.43 & 0.198 & 0.659 \\
\hline Rump circumference & 42.85 & 42.75 & 42.93 & 38.12 & 6.51 & 0.214 & 0.355 \\
\hline Thigh circumference & 31.78 & 32.62 & 32.25 & 30.37 & 2.61 & 0.290 & 0.191 \\
\hline Leg length & 41.14 & 41.62 & 40.62 & 39.75 & 2.20 & 0.173 & 0.442 \\
\hline
\end{tabular}

* Standard error of the mean.

Table 5. Qualitative traits of the longissimus lumborum muscle of feedlot goats fed diets containing cottonseed cake replacing soybean meal.

\begin{tabular}{|c|c|c|c|c|c|c|c|}
\hline \multirow[t]{2}{*}{ Item } & \multicolumn{4}{|c|}{$\begin{array}{l}\text { Cottonseed cake level } \\
\text { (g/kg per dry matter) }\end{array}$} & \multirow[t]{2}{*}{ SEM $^{1}$} & \multicolumn{2}{|c|}{$P$ value } \\
\hline & 0 & 330 & 660 & 1000 & & Linear & Quadratic \\
\hline $\mathrm{pH}$ & 6.46 & 6.71 & 6.51 & 6.53 & 0.28 & 0.500 & 0.959 \\
\hline Color $^{2}$ & - & - & - & - & - & - & - \\
\hline$L^{*}$ & 37.62 & 36.21 & 37.15 & 38.61 & 2.28 & 0.303 & 0.114 \\
\hline$a^{*}$ & 19.39 & 19.67 & 19.98 & 19.39 & 1.61 & 0.180 & 0.290 \\
\hline$b^{*}$ & 6.02 & 5.15 & 5.39 & 5.11 & 1.11 & 0.225 & 0.455 \\
\hline Cooking losses, $\mathrm{g} / \mathrm{kg}$ & 261.2 & 224.6 & 292.4 & 256.6 & 62.2 & 0.282 & 0.059 \\
\hline Shear force, N/cm & 19.32 & 17.55 & 18.83 & 19.81 & 0.43 & 0.157 & 0.656 \\
\hline
\end{tabular}

${ }^{1}$ Standard error of the mean. ${ }^{2} L^{*}$ : lightness. $a^{*}$ : redness. $b^{*}$ : yellowness.

tonseed cake did not promote positive or negative changes in the productive traits of the goats. These results were also observed in lambs fed with the same levels of substitution of soybean meal for cottonseed cake (R. V. M. M. Silva et al., 2016).

Hot carcass yield and LEA were higher than the values described in many other studies with goats (Silva et al., 2011; Browning et al., 2012; Yusuf et al., 2014). This fact suggests that the animals evaluated in the present study had a good genetic constitution and were properly managed and fed.

The results obtained for LEA and BFT can be attributed to the fact that the goats were slaughtered at similar body weights, which corroborates the following inference drawn by Osório (2002): in carcasses of similar weights and fatness degrees, practically all body regions will have similar proportions, irrespective of the breed. In this study, this assertion was confirmed by the yield of primal cuts and the carcass morphometric measurements (Tables 3 and 4).

Loin-eye area and BFT are traits used as indicators of muscularity and degree of fatness in the carcass, respectively (Matarim, 2015). The carcass cuts, in turn, depend on their appearance to ensure a more effective utilization of the meat, allowing for increased selling prices (FAO, 1991).
Although no changes were detected in the carcass biometric measurements, these assessments are important in a production system, considering that such measurements are correlated with in vivo measurements and can be used along with them or separately (Bautista-Díaz et al., 2017).

The higher $\mathrm{pH}$ value of goat meat is probably related to species rather than diet, considering that the $\mathrm{pH}$ of goat meat is higher (Shija et al., 2013). The average meat $\mathrm{pH}$ value (6.55) recorded in this study was close to the 6.55 observed by Shija et al. (2013) and to the 6.53 reported by Pophiwa et al. (2017) in goat meat immediately after slaughter. Those authors also observed a decline curve of natural $\mathrm{pH}$ until its stabilization, between 5.4 and 5.8, which is considered normal for this species (Puolanne, 2017). The meat of the animals evaluated in the current study behaved likewise, suggesting normal rigor mortis development and inexistence of pre-slaughter stress (Della Malva et al., 2016; Pereira et al., 2016; T. M. Silva et al., 2016). Therefore, meat quality would not be compromised (Gallo et al., 2018).

Results for meat color, CL, and SF (Table 5) were similar to those reported by Ribeiro et al. (2018), who examined the meat quality of feedlot Boer crossbred goats fed diets that also contained biodiesel by-products. Meat color is the ba- 
Table 6. Centesimal composition ( $\mathrm{g} / \mathrm{kg}$ ) and cholesterol content $(\mathrm{mg} / 100 \mathrm{~g}$ of meat) of the longissimus lumborum muscle of feedlot goats fed diets containing cottonseed cake replacing soybean meal.

\begin{tabular}{|c|c|c|c|c|c|c|c|}
\hline \multirow[t]{2}{*}{ Item } & \multicolumn{4}{|c|}{$\begin{array}{l}\text { Cottonseed cake level } \\
\text { (g/kg per dry matter) }\end{array}$} & \multirow[t]{2}{*}{ SEM $^{1}$} & \multicolumn{2}{|c|}{$P$ value } \\
\hline & 0 & 330 & 660 & 1000 & & Linear & Quadratic \\
\hline Moisture & 741.0 & 747.1 & 750.1 & 747.6 & 15.8 & 0.459 & 0.084 \\
\hline Mineral matter ${ }^{2}$ & 10.8 & 10.7 & 9.3 & 9.7 & 0.6 & 0.001 & 0.277 \\
\hline Protein & 214.9 & 208.1 & 207.6 & 210.3 & 7.8 & 0.202 & 0.325 \\
\hline Total lipids & 33.3 & 34.1 & 33.0 & 32.4 & 7.8 & 0.095 & 0.060 \\
\hline Cholesterol $^{3}$ & 50.85 & 61.83 & 66.48 & 70.55 & 12.12 & 0.006 & 0.564 \\
\hline
\end{tabular}

${ }^{1}$ Standard error of the mean. ${ }^{2} Y=10.825-0.0014 x, R^{2}=0.67 .{ }^{3} Y=52.917+0.0192 x, R^{2}=0.93$.

sic qualitative attribute that most influences the consumer's choice, eliciting their interest in consuming or rejecting the product (Suman and Joseph, 2012). Color is an attribute affected by the physical and chemical characteristics of meat, such as $\mathrm{pH}$, marbling, thickness of subcutaneous fat, and lipid and moisture content (Webb, 2014). Therefore, the lack of effect of cottonseed cake on the color of the meat may be correlated to the lack of effect of this on the physical and chemical values of the meat.

Cooking loss, in turn, is an important parameter in the evaluation of meat quality, as it is associated with the yield of meat during preparation for consumption, besides influencing its juiciness and tenderness (Campos et al., 2017). Lastly, texture is the most important factor in determining meat quality from the consumer's perspective, since it is related to how easily the meat is chewed as well as to sensations perceived by the consumer upon chewing (Mennecke et al., 2007; Liu et al., 2017). These three attributes are among those deemed most important at the time of purchase of meat (Madruga et al., 2008; Girard et al., 2016; Muela et al., 2016).

The centesimal composition of the longissimus lumborum of the goats evaluated in this study was close to values described in the literature for goat meat (Kessler et al., 2014; T. M. Silva et al., 2016; Ribeiro et al., 2018). The centesimal composition of meat is important because it basically expresses its nutritional value as well as the proportion of each nutrient in the diet.

Although the cholesterol contents in the goats' meat increased with the dietary replacement, the observed values were lower than the $75 \mathrm{mg} / 100 \mathrm{~g}$ of goat meat recommended by the U.S. Department of Agriculture (USDA, 2011). They agree, however, with the 64.48 and $69.89 \mathrm{mg} / 100 \mathrm{~g}$ of meat found by Madruga et al. (2005) in Boer crossbred and unidentified-breed goats, respectively, $63.92 \mathrm{mg} / 100 \mathrm{~g}$ of meat in native goats reported by Bonvillani et al. (2010), and $74.76 \mathrm{mg} / 100 \mathrm{~g}$ of meat in Angora crossbred goats described by Kessler et al. (2014). Based on the cholesterol values found in the goats' meat in the present study, it is possible to state that their meat can make up a healthy diet, considering that the World Health Organization recommends a daily cholesterol intake of less than $300 \mathrm{mg}$ or $200 \mathrm{mg}$ for people with a history of heart disease.

\section{Conclusions}

Replacing soybean meal with cottonseed cake in feedlot goat diets does not compromise the carcass traits or meat quality of those animals. We recommend using up to $100 \%$ of cottonseed cake as the protein source in feedlot goat diets.

Data availability. The original data used in this study are available from the corresponding author upon request.

Author contributions. GGPdC, EMS, and AJVP were responsible for the conceptualization and study design. BMAdC and DdSP performed data analysis. DYCdA, FAdO, AALdG, and CdON collected the data. LGAC and HDRA wrote and edited the manuscript. All authors contributed to refining the text and approved the final version to be submitted.

Competing interests. The authors declare that they have no conflict of interest.

Disclaimer. Publisher's note: Copernicus Publications remains neutral with regard to jurisdictional claims in published maps and institutional affiliations.

Review statement. This paper was edited by Manfred Mielenz and reviewed by two anonymous referees. 


\section{References}

Allen, M. S.: Drives and limits to feed intake in ruminants, Anim. Prod. Sci., 54, 1513-1524, https://doi.org/10.1071/AN14478, 2014.

AOAC: Association of Official Analytical Chemists (Eds.): Official Methods of Analysis of AOAC International AOAC, Arlington, VA, 1990.

AOAC: Association of Official Analytical Chemists (Eds.): Official Methods of Analysis of AOAC International AOAC, Arlington, VA, 2002.

Bautista-Díaz, E., Cuytun-Salazar, R., Chay-Canul, A. J., Herrera, R. A. G., Piñeiro-Vázquez, A. T., Monforte, J. G. M., Tedeschi, L. O., Cruz-Hernández, A., and Gómez-Vázquez, A.: Determination of carcass traits in Pelibuey ewes using biometric measurements, Small Rum. Res., 147, 115-119, https://doi.org/10.1016/j.smallrumres.2016.12.037, 2017.

Bonvillani, A., Peña, F., Domenech, V., Polvillo, O., García, P. T., and Casal, J. J.: Meat quality of Criollo Cordobes goat kids produced under extensive feeding conditions, Effects of sex and age/weight at slaughter, Span. J. Agric. Res., 8, 116-125, https://doi.org/10.5424/sjar/2010081-1150, 2010.

Browning Jr., R., Phelps, O., Chisley, C., Getz, W. R., Hollis, T., and Leite-Browning, M. L.: Carcass yield traits of kids from a complete diallel of Boer, Kiko, and Spanish meat goat breeds semiintensively managed on humid subtropical pasture, J. Anim. Sci., 90, 709-722, https://doi.org/10.2527/jas.2011-3999, 2012.

Campos, F. S., Carvalho, G. G. P., Santos, E. M., Araújo, G. G. L., Gois, G. C., Rebouças, R. A., Leão, A. G., Santos, S. A., Oliveira, J. S., Leite, L. C., Araújo, M. L. G. M. L., Cirne, L. G. A., Silva, R. R., and Carvalho, B. M. A.: Influence of diets with silage from forage plants adapted to the semi-arid conditions on lamb quality and sensory attributes, Meat Sci., 124, 6168, https://doi.org/10.1016/j.meatsci.2016.10.011, 2017.

Castro, W. J. R., Zanine, A. M., Ferreira, D. J., Souza, A. L., Pinho, R. M. A., Parente, M. O. M., Parente, H. N., and Santos, E .M.: Delinted cottonseed in diets for finishing sheep, Trop. Anim. Health Prod., 52, 2461-2468, https://doi.org/10.1007/s11250019-02134-3, 2020.

Della Malva, A., Albenzio, M., Annicchiarico, G., Caroprese, M., Muscio, A., Santillo, A., and Marino, R.: Relationship between slaughtering age, nutritional and organoleptic properties of Altamurana lamb meat, Small Rum. Res., 135, 39-45, https://doi.org/10.1016/j.smallrumres.2015.12.020, 2016.

Detman, E. and Valadares Filho, S. C.: On the estimation of non-fibrous carbohydrates in feeds and diets, Arq. Bras. Med. Vet. Zootec., 62, 980-984, https://doi.org/10.1590/S010209352010000400030, 2010.

Dubeuf, J. P.: The social and environmental challenges faced by goat and small livestock local activities: Present contribution of research-development and stakes for the future, Small Rum. Res., 98, 3-8, https://doi.org/10.1016/j.smallrumres.2011.03.008, 2011.

FAO: Food and Agriculture Organization (Eds.): Guidelines for slaughtering, meat cutting and further processing, Meat cutting an utilization of meat cuts, available at: http://www.fao.org/3/ t0279e/T0279E00.htm\#TOC (last access: 18 July 2020), 1991.

FAO: Food and Agriculture Organization (Eds.): Guidelines for humane handling, transport and slaughter of livestock, Slaughter of livestock, available at: http://www.fao.org/3/a-x6909e.pdf (last acesse: 25 July 2020), 2001.

Gallo, C., Tarumán, J., and Larrondo, C.: Main Factors Affecting Animal Welfare and Meat Quality in Lambs for Slaughter in Chile, Animals, 8, 165-184, https://doi.org/10.3390/ani8100165, 2018.

Girard, M., Dohme-Meier, F., Silacci, P., Kragten, S. A., Kreuzer, M., and Bee, G.: Forage legumes rich in condensed tannins may increase n-3 fatty acid levels and sensory quality of lamb meat, J. Sci. Food Agric., 96, 1923-1933, https://doi.org/10.1002/jsfa.7298, 2016.

Gonzaga Neto, S., Oliveira, R. L., Lima, F. H., Medeiros, A. N., Bezerra, L. R., Viégas, J., Nascimento Júnior, N. G., and Freitas Neto, M. D.: Milk production, intake, digestion, blood parameters, and ingestive behavior of cows supplemented with byproducts from the biodiesel industry, Trop. Anim. Health Prod., 47, 191-200, https://doi.org/10.1007/s11250-014-0706-2, 2015.

Iñiguez, L.: The challenges of research and development of small ruminant production in dry areas, Small Rum. Res., 98, 12-20, https://doi.org/10.1016/j.smallrumres.2011.03.010, 2011.

Kessler, J. D., Osório, M. T. M., Nörnberg, J. L., Osório, J. C. S., Esteves, R. M. G., Souza, A. P. B., Arnoni, R. K., Borba, M. S., Oliveira, R. M., and Ferreira, O. G. L.: Chemical composition of meat from kids slaughtered at different ages, Arch. Zootec., 63, 153-160, 2014.

Liu, D., Deng, Y., Sha, L., Hashem M. A., and Gai, S.: Impact of oral processing on texture attributes and taste perception, J. Food Sci. Technol., 54, 2585-2593, https://doi.org/10.1007/s13197017-2661-1, 2017.

Madruga, M. S., Narain, N., Duarte, T. D., Sousa, W. H., Galvão, M. S., Cunha, M. G. G., and Ramos, J. L. F.: Chemical and sensorial characteristics of commercial meat cuts of "mesticos" and Boer goats, Ciênc. Tecnol. Aliment., 25, 713-719, https://doi.org/10.1590/S0101-20612005000400014, 2005.

Madruga, M. S., Galvão, M. S., Costa, R. G., Beltrão, S. E. S., Santos, N. M., Carvalho, F. M., and Viaro, V. D.: Aroma profile and chemical quality of goat Saanen meat fed with different levels of concentrate, R. Bras. Zootec., 37, 936-943, https://doi.org/10.1590/S1516-35982008000500023, 2008.

Matarim, D. L.: Estimation of genetic parameters for carcass traits measured by ultrasound, with emphasis on intramuscular fat, in Nellore, Ph.D. thesis, Faculty of Animal Science and Food Engineering, University of São Paulo, Pirassununga, 55 pp., 2015.

McGrath, J., Duval, S. M., Tamassia, L. F. M., Kindermann, M., Stemmler, R. T., Gouvea, V. N., Acedo, T. S., Immig, I., Williams, S. N., and Celi, P.: Nutritional strategies in ruminants: A lifetime approach, Res. Vet. Sci., 116, 28-39, https://doi.org/10.1016/j.rvsc.2017.09.011, 2018.

Mennecke, B. E., Townsend, A. M., Hayes, D. J., and Lonergan, S. M.: A study of factors that influence consumer attitudes toward beef products using the conjoint market analysis tool, J. Anim. Sci., 85, 2639-2659, https://doi.org/10.2527/jas.2006-495, 2007.

Miltenburg, G. A. J., Wensing, T. H., and Smulders, F. J. M.: Relationship between blood hemoglobin, plasma and tissue iron, muscle heme pigment, and carcass color of veal, J. Anim. Sci., 70, 2766-2772, https://doi.org/10.2527/1992.7092766x, 1992.

Mohammed, A. S., Animut, G., Urge, M., and Assefa, G.: Grazing behavior, dietary value and performance of sheep, goats, cattle and camels co-grazing range with mixed species of 
grazing and browsing plants, Vet. Anim. Sci., 10, 100154, https://doi.org/10.1016/j.vas.2020.100154, 2020.

Muela, E., Monge, P., Sañudo, C., Campo, M. M., and Beltrán, J. A.: Sensory quality of lamb following long-term frozen storage, Meat Sci., 114, 32-37, https://doi.org/10.1016/j.meatsci.2015.12.001, 2016.

NRC - National Research Council (Eds.): Nutrient Requirements of Small Ruminants: Sheep, Goats, Cervids and New World Camelids, The National Academy Press, Washington, DC, 384 pp., 2007.

Oliveira, R. L., Lima, L. S., Garcez Neto, A. R., Bagaldo, C. L., and Silva, T. M.: Licury oil supplements for lactating cows on pasture, Can. J. Anim. Sci., 95, 617-624, https://doi.org/10.4141/cjas-2014-165, 2015.

Osório, J. C. S., Oliveira, N. M., Osório, M. T. M., Jardim, R. D., and Pimentel, M. A.: Meat production in male lambs derived from the crossing between border leicester rams with corriedale and polwarth ewes, Braz. J. Anim. Sci.., 31, 1469-1480, https://doi.org/10.1590/S1516-35982002000600019, 2002.

Pereira, L., Pires, A. J. V., Carvalho, G. G. P., Silva, R. V. M. M., Simionato, J. I., Lacerda, E. C. Q., Bezerra, L. S., Eiras, C. E., and Carvalho, B. M. A.: Nutritional Characteristics of Lambs Meat Fed Diets with Cotton Cake, J. Food Qual., 39, 140-149, https://doi.org/10.1111/jfq.12184, 2016.

Pophiwa, P., Webb, E. C., and Frylinck, L.: Carcass and meat quality of Boer and indigenous goats of South Africa under delayed chilling conditions, S. Afr. J. Anim. Sci., 47, 794-803, https://doi.org/10.4314/sajas.v47i6.7, 2017.

Puolanne, E.: Development in our understanding of water-hoding capacity in meat, in: New aspects of meat quality: from genes to ethics, edited by: Purslow, P. P., Woodhead Publishing, Cambridge, 167-187, 2017.

Rekwot, P. I.: Effects of feeding maize stover and cottonseed cake on onset of puberty in Bunaji (Bos indicus) heifers, Trop. Anim. Health Produc., 36, 637-644, https://doi.org/10.1023/b:trop.0000042854.64345.38, 2004.

Resende, K. T., Fernandes, M. H. M. R., Hentz, F., Teixeira, I. A. M. A., and Garcia, J. A.: Methods of body composition estimative of growing goats, Acta Scient., 39, 189-194, https://doi.org/10.4025/actascianimsci.v39i2.33215, 2017.

Ribeiro, R. D. X., Medeiros, A. N., Oliveira, R. L., Araújo, G. G. L., Queiroga, R. C. R. E., Ribeiro, M. D., Silva, T. M., Bezerra, L. R., and Oliveira, R. L.: Palm kernel cake from the biodiesel industry in goat kid diets, Part 2: Physicochemical composition, fatty acid profile and sensory attributes of meat, Small Rum. Res., 165, 17, https://doi.org/10.1016/j.smallrumres.2018.05.014, 2018.

SAS: Statistical Analysis System, Version 9.2, SAS Institute Inc, Cary, NC, 2009.

Shija, D. S., Mtenga, L. A., Kimambo, A. E., Laswai, G. H., Mushi, D. E., Mgheni, D. M., Mwilawa, A. J., Shirima, E. J. M., and Safari, J. G.: Chemical Composition and Meat Quality Attributes of Indigenous Sheep and Goats from Traditional Production System in Tanzania, Asian-Aust. J. Anim. Sci., 26, 295-302, https://doi.org/10.5713/ajas.2012.12432, 2013.
Silva, R. V. M. M., de Carvalho, G. G. P., Pires, A. J. V., Pereira, M. L. A., Pereira, L., Campos, F. S., Perazzo, A. F., de Araújo, M. L. G. M. L., Nascimento, C. O., Santos, S. A., Tsoto, M. S. L., Rufino, L. M. A., and de Carvalho, B. M. A.: Cottonseed cake in substitution of soybean meal in diets for finishing lambs, Small Rumin. Res., 137, 183-188, https://doi.org/10.1016/j.smallrumres.2016.03.014, 2016.

Silva, T. M., Oliveira, R. L. O., Barbosa, L. P., Garcez Neto, A. F., Bagaldo, A. R., Lanna, D. P. D. L., Silva, M. C. A., and Jesus, I. B.: Preliminary Study on Meat Quality of Goats Fed Levels of Licury Oil in the Diet, Asian-Aust. J. Anim. Sci., 24, 1112-1119, https://doi.org/10.5713/AJAS.2011.11053, 2011.

Silva, T. M., Medeiros, A. N., Oliveira, R. L., Gonzaga Neto, S., Queiroga, R. C., Ribeiro, A. G., and Bezerra, L. R.: Carcass traits and meat quality of crossbred Boer goats fed peanut cake as a substitute for soybean meal, J. Anim. Sci., 94, 2992-3002, https://doi.org/10.2527/jas.2016-0344, 2016.

Silva Sobrinho, A. G., Kadim, I. T., and Purchas, R. W.: Effect of genotypes and age on carcass and meat quality characteristics of ram lambs, Agr. Mar. Sci., 8, 73-78, 2003.

Suman, S. P. and Joseph, P.: Myoglobin chemistry and meat color, Annu. Rev. Food Sci. Technol., 4, 79-99, https://doi.org/10.1146/annurev-food-030212-182623, 2013.

USDA: Goat, cooked, roasted. NBD No: 17169. Nutrient values and weights are for edible portion, in: National nutrient database for Standard Reference, Release 18, United States Departament of Agricultural, Nutrient Data Laboratory, Washington, DC, 2011.

Van Soest, P. J., Robertson, J. B., and Lewis, B. A.: Methods for dietary fiber, neutral detergent fiber, and nonstarch polyssacharides in relation to animal nutrition, J. Dairy Sci., 74, 3583-3597, https://doi.org/10.3168/jds.S0022-0302(91)78551-2, 1991.

Webb, E. C.: Goat meat production, composition, and quality, Anim. Front., 4, 33-37, https://doi.org/10.2527/af.2014-0031, 2014.

Weiss, W. P.: Energy prediction equations for ruminant feeds, Proceedings of the Cornell Nutrition Conference for Feed Manufacturers, 61, 176-185, https://doi.org/10.1590/S0103$90162005000100015,1999$.

Wheeler, T. L., Koohmaraie, M., and Shackelford, S. D.: Standardized warner bratzler shear force procedures for meat tenderness measurement, Marc USDA, Clay Center, NE, 1995.

Yusuf, A. L., Goh, Y. M., Samsudin, A. A., Alimon, A. R., and Sazili, A. Q.: Growth Performance, Carcass Characteristics and Meat Yield of Boer Goats Fed Diets Containing Leaves or Whole Parts of Andrographis paniculata, Asian-Aust. J. Anim. Sci., 27, 503-510, https://doi.org/10.5713/ajas.2013.13533, 2014. 